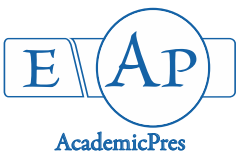

Ramakrishna B and Srinivasulu C (2021)

Notulae Scientia Biologicae

Volume 13, Issue 3, Article number 10977

DOI: $10.15835 / \mathrm{nsb} 13310977$

Research Article

\title{
Diversity and distribution of Asian forest scorpions (Arthropoda, Scorpionidae, Heterometrinae) in Telangana State, India
}

\author{
Bagari RAMAKRISHNA, Chelmala SRINIVASULU*
}

Osmania University, College of Science, Department of Zoology, Hyderabad, Telangana State 500007 , India;

raam27@gmail.com; chelmalasrinivasulu@gmail.com (*correspondingauthor)

\begin{abstract}
Asian forest scorpions belong to the subfamily Heterometrinae and include some of the poorly known scorpion fauna in India in general and Telangana State in particular. The Asian forest scorpions occur in South Asia and Southeast Asia and are known from Pakistan in west to the Philippines in the east. There are 27 species of Asian forest scorpions belonging to seven genera Chersonesometrus, Deccanometrus, Gigantometrus, Heterometrus, Javanimetrus, Sahyadrimetrus and Srilankametrus known from India. These are the largebodied scorpions that are subjected to killing and local collections. Information on their distribution and current taxonomy is not complete. We provide the updated taxonomy, description and distribution maps of four species of Asian forest scorpions known to occur in Telangana State, India.
\end{abstract}

Keywords: Chersonesometrus; Deccanometrus; Gigantometrus; Heterometrus, mapping

\section{Introduction}

The Asian forest scorpions belong to the subfamily Heterometrinae of the family Scorpionidae. These are characterized by their large size (up to $180 \mathrm{~mm}$ in length) (Pocock, 1900; Couzijn, 1981; Tikader and Bastawade, 1983; Sissom, 1990; Kovařík, 2004). They occur in South and Southeast Asia and range from Pakistan to Indonesia and Philippines (Prendini and Loria, 2020). They occur in tropical and sub-tropical rainforests, moist and dry tropical deciduous forests, tropical thorn forests (Tahir and Prendini, 2014), and also in secondary habitats such as fallows and plantations.

These are fossorial, and their burrows are found (that could be simple with single entrance to complex with multi entrances) in loamy soils near waterbodies, in open fallows and meadows, at the base of the large boulders or rocks and also at the base of the large trees (Shivashanker, 1994; Sureshan et al., 2007; Javed et al., 2010; Mirza et al., 2012; Tahir and Prendini, 2014). Most species are usually black or brown or reddish brown, while a few have pale (yellowish to reddish) legs and telson. They are mildly venomous; they seldom do attack, but usually deter attackers by snapping their pedipalp chelae accompanied by stinging action and stridulating noise (Prendini et al., 2003).

Taxonomically, until recently all the Asian forest scorpions have been included under the genus Heterometrus Ehrenberg, 1828. The first systematic revision of the genus was done by Kraepelin (1899) who has recognized 13 species in this genus. Couzijn $(1978,1981)$ provided the revision and proposed to accommodate 21 species of Asian forest scorpions in five subgenera, namely, nominotypical Heterometrus

Received: 15 May 2021. Received in revised form: 02 Aug 2021. Accepted: 11 Aug 2021. Published online: 18 Aug 2021.

From Volume 13, Issue 1, 2021, Notulae Scientia Biologicae journal uses article numbers in place of the traditional method of continuous pagination through the volume. The journal will continue to appear quarterly, as before, with four annual numbers. 
(Ehrenberg, 1828); Chersonesometrus (Couzijn, 1978); Gigantometrus (Couzijn, 1978); Javanimetrus (Couzijn, 1981); and Srilankametrus (Couzijn, 1981). Prendini et al. (2003) and Kovařík (2004) revised the genus Heterometrus. Rossi (2016) revalidated the subfamily Heterometrini (Simon, 1879) to accommodate the Asian scorpionids, and revalidated subgenera Gigantometrus.

The application of molecular taxonomy tools to understand the phylogenetic relationships commenced in the late 1990s through the works of Prendini (2000) and Prendini et al. (2003). Prendini and Loria (2020), and Loria and Prendini (2021) provided the first species-level phylogenetic analysis of Asian Scorpionidae based on 186 morphological characters, two nuclear, and three mitochondrial loci, and provided a systematic revision of the Asian forest scorpions along with the revision of the suprageneric classification under the subfamily Heterometrinae. Prendini and Loria (2020) established new genera - Deccanometrus and Sahyadrimetrus, to accommodate seven species in the former and six species (including two new species Sahyadrimetrus mathewi and S. tikaderi) in the latter. Loria and Prendini (2020) have established that the Asian forest scorpions separated from their African ancestors after the Indian subcontinent plate separated from Africa, lost their range during the KT mass extinction event and got restricted to southern Western Ghats in India and the Central Highlands in Sri Lanka, recolonized Deccan Plateau and north India, and dispersed, at least three times, to Southeast Asia.

The research on the Asian forest scorpions in India is limited to taxonomy and occasional sighting records (Mirza et al., 2012; Bastawade et al., 2012). The scorpion diversity of Telangana State has been sporadically explored and only 13 species have been documented so far (Mohapatra, 2021).

Through this contribution we share the evidence-based observations on the four Asian forest scorpion species occurring in Telangana State along with their distribution maps.

\section{Materials and Methods}

Opportunistic surveys to detect the Asian forest scorpions were conducted in different parts of Telangana State between March 2013 and March 2019. We have followed Visual Encounter Surveys to detect the scorpions and collected them using active collection methods including night surveys with black light and rock-rolling to detect their presence. When encountered, they were captured carefully using long forceps by holding the tip of their tail without harming the animal. A few voucher specimens were collected. The collections of voucher specimens were minimal. The voucher specimens are deposited in the Natural History Museum of Osmania University, Hyderabad.

The following external measurements (in $\mathrm{mm}$ ) was taken using digital vernier caliper: Total length; Carapace (Length, Width); Mesosoma (Length, Width) Metasoma-telson (Length); Metasoma segment-I (Length, Width); Metasoma segment-II (Length, Width); Metasoma segment-III (Length, Width); Metasoma segment-IV (Length, Width); Metasoma segment-V (Length, Width); Telson length (Length); Pedipalp \& femur (Length, Width); patella (Length, Width); tibia (Length, Width); movable finger (Length). Pectinal teeth count was also taken using a Leica stereo-microscope. Identification of scorpions was done following Pocock (1900), Tikader and Bastawade (1983), and Kovarik (2004).

\section{Results}

A total of four species of Asian forest scorpions belonging to three genera [Chersonesometrus Couzijn, 1978; Gigantometrus Couzijn, 1978; and Deccanometrus Prendini and Loria, 2020] were recorded in Telangana State during the present study (Figures 1a-c). The taxonomy, characteristics and distribution are provided below. 


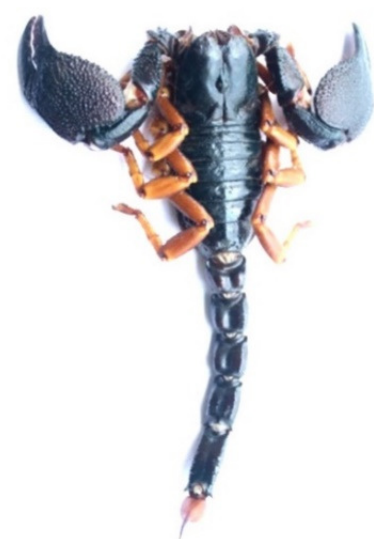

a

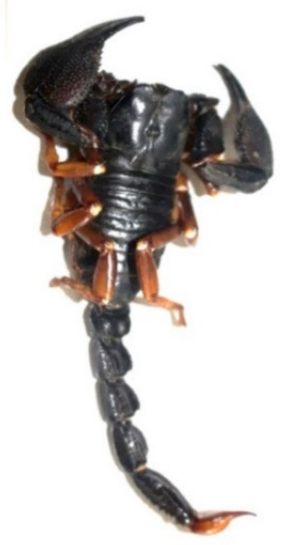

b

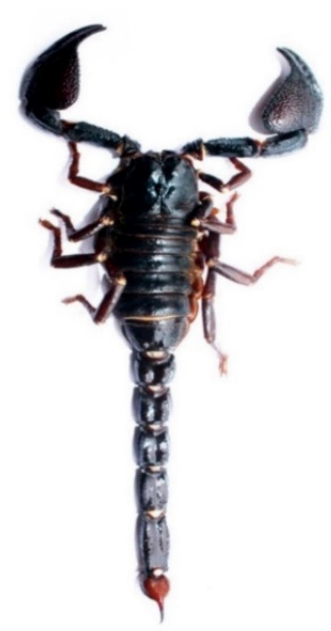

c

Figure 1. Asian forest scorpions of Telangana State, India [a. Chersonesometrus fulvipes (C.L. Koch, 1837); b. Chersonesometrus madraspatensis (Pocock, 1900); and c. Gigantometrus swammerdami (Simon, 1872)]

Family Scorpionidae Latreille, 1802

Scorpionidae comprises 18 genera and 152 species grouped into four extant subfamilies: Heterometrinae (Simon, 1879); Opistophthalminae (Rossi, 2016); Pandininae (Thorell, 1876); Scorpioninae (Latreille, 1802) (Prendini and Loria, 2020).

Subfamily Heterometrinae Simon, 1879

Heterometrinae are endemic to Asia, with greatest species richness and endemism in India, followed by Indonesia (Prendini and Loria, 2020). The species diversity of the subfamily Heterometrinae is represented by 41 species belonging to the following seven genera - Chersonesometrus (Couzijn, 1978); Deccanometrus (Prendini and Loria, 2020); Gigantometrus (Couzijn, 1978); Heterometrus (Ehrenberg, 1828); Javanimetrus (Couzijn, 1981); Sahyadrimetrus (Prendini and Loria, 2020); and Srilankametrus (Couzijn, 1981). Species belonging to all the five genera are reported from mainland India with the exception of the genera Heterometrus and Javanimetrus that are known only from Andaman and Nicobar Islands.

\section{Genus Chersonesometrus Couzijn, 1978}

Type species by original designation: Buthus fulvipes C.L. Koch, 1837 [= Chersonesometrus fulvipes (C.L. Koch, 1837)]

Endemic to India. It includes 10 species - Chersonesometrus bastawadei Prendini and Loria, 2020; Chersonesometrus beccaloniae (Kovařik, 2004); Chersonesometrus fulvipes (C.L. Koch, 1837); Chersonesometrus hendersoni Prendini and Loria, 2020; Chersonesometrus madraspatensis (Pocock, 1900); Chersonesometrus nathanorum Prendini and Loria, 2020; Chersonesometrus pelekomanus (Couzijn, 1981); Chersonesometrus shivashankariPrendini and Loria, 2020; Chersonesometrus tristis(Henderson, 1919); and Chersonesometrus wroughtoni (Pocock, 1899).

Two species, C. fulvipes (C.L. Koch, 1837) and C. madraspatensis (Pocock, 1900), are known from Telangana State. 
Chersonesometrus fulvipes (C.L. Koch, 1837)

Buthus fulvipes C.L. Koch, 1837: 45, 46, pl. CXXI, fig. 278

Material examined: 1 Male NHM.OU.ARACH.1.2018 collected from Cherial (17.548N \& 78.126E), Sangareddy District, Telangana State; collected by B. Ramakrishna.

Identification (Figure 1a): Adult male (Total length $100.0 \mathrm{~mm}$; Table 1) uniformly dark reddish brown, with yellowish legs. The telson is lighter than the rest of the body. The femur and patella of the pedipalp is long. Chela is lobiform with a length-to-width ratio of 1.7. Large, round granules with no carinae cover the manus. Patella of pedipalp lacks prominent internal tubercle. On the lateral section, the granulation is weak and sparse. Carapace is granulating at the edges and tuberculate in the front. Moveable finger as long as the carapace length. The counts of pro- and retroventral spiniform macrosetae on the leg telotarsi are 4/5, 4/5, 4/6 \& 4/6. Pectinal teeth number $14 / 15$ on either side. Telson is hirsute, with a vesicle as long as the aculeus.

Distribution: This species was detected only once during the present study at Cherial, Sangareddy District, Telangana Sate (Figure 2). However, it was also reported from Tharigoppula, Jangaon District (Kovař́ík, 2004; Mohapatra, 2021).

Table 1. Morphometry of the representative specimen of the four species of Asian forest scorpions known from Telangana State, India (measurement, in $\mathrm{mm}$ )

\begin{tabular}{|c|c|c|c|c|}
\hline \multirow{2}{*}{ Character } & \multicolumn{4}{|c|}{ Species* } \\
\hline & C. ful. & C. mad. & G. swa. & D. xan. \\
\hline Total length & 100.00 & 53.15 & 124.98 & 66.53 \\
\hline Carapace length & 16.30 & 7.99 & 17.66 & 11.59 \\
\hline Carapace width & 15.00 & 7.29 & 16.88 & 9.04 \\
\hline \multicolumn{5}{|l|}{ Metasoma and telson } \\
\hline Segment I length & 5.97 & 3.10 & 10.51 & 3.60 \\
\hline Segment I width & 7.75 & 3.25 & 8.09 & 4.59 \\
\hline Segment II length & 7.46 & 3.37 & 11.46 & 3.99 \\
\hline Segment II width & 6.58 & 2.90 & 7.06 & 3.84 \\
\hline Segment III length & 8.28 & 3.56 & 11.60 & 4.10 \\
\hline Segment III width & 6.68 & 2.64 & 7.06 & 3.93 \\
\hline Segment IV length & 10.11 & 4.25 & 13.19 & 5.01 \\
\hline Segment IV width & 5.64 & 2.37 & 6.70 & 3.51 \\
\hline Segment V length & 12.60 & 5.24 & 14.84 & 6.49 \\
\hline Segment V width & 5.12 & 2.15 & 6.42 & 3.29 \\
\hline Telson length & 12.52 & 6.63 & 16.08 & 7.86 \\
\hline \multicolumn{5}{|l|}{ Pedipalp } \\
\hline Femur length & 11.38 & 5.31 & 12.62 & 6.27 \\
\hline Femur width & 5.22 & 2.58 & 6.08 & 3.62 \\
\hline Patella length & 13.20 & 6.10 & 12.08 & 7.93 \\
\hline Patella width & 5.74 & 2.84 & 6.08 & 3.80 \\
\hline Tibia length & 25.50 & 11.73 & 28.88 & 16.50 \\
\hline Tibia width & 14.75 & 5.24 & 15.49 & 8.36 \\
\hline Moveable finger length & 16.17 & 7.45 & 18.64 & 9.56 \\
\hline Pectinal teeth & $14 / 15$ & $15 / 16$ & $18 / 18$ & $11 / 11$ \\
\hline Chela length-to-width ratio & 1.7 & 2.2 & 1.8 & 1.9 \\
\hline
\end{tabular}

${ }^{*}$ C. ful. - Chersonesometrus fulvipes (C.L. Koch, 1837); C. mad. - Chersonesometrus madraspatensis (Pocock, 1900); G. swa. - Gigantometrus swammerdami (Simon, 1872); and D. xan. - Deccanometrus xanthopus (Pocock, 1897) 


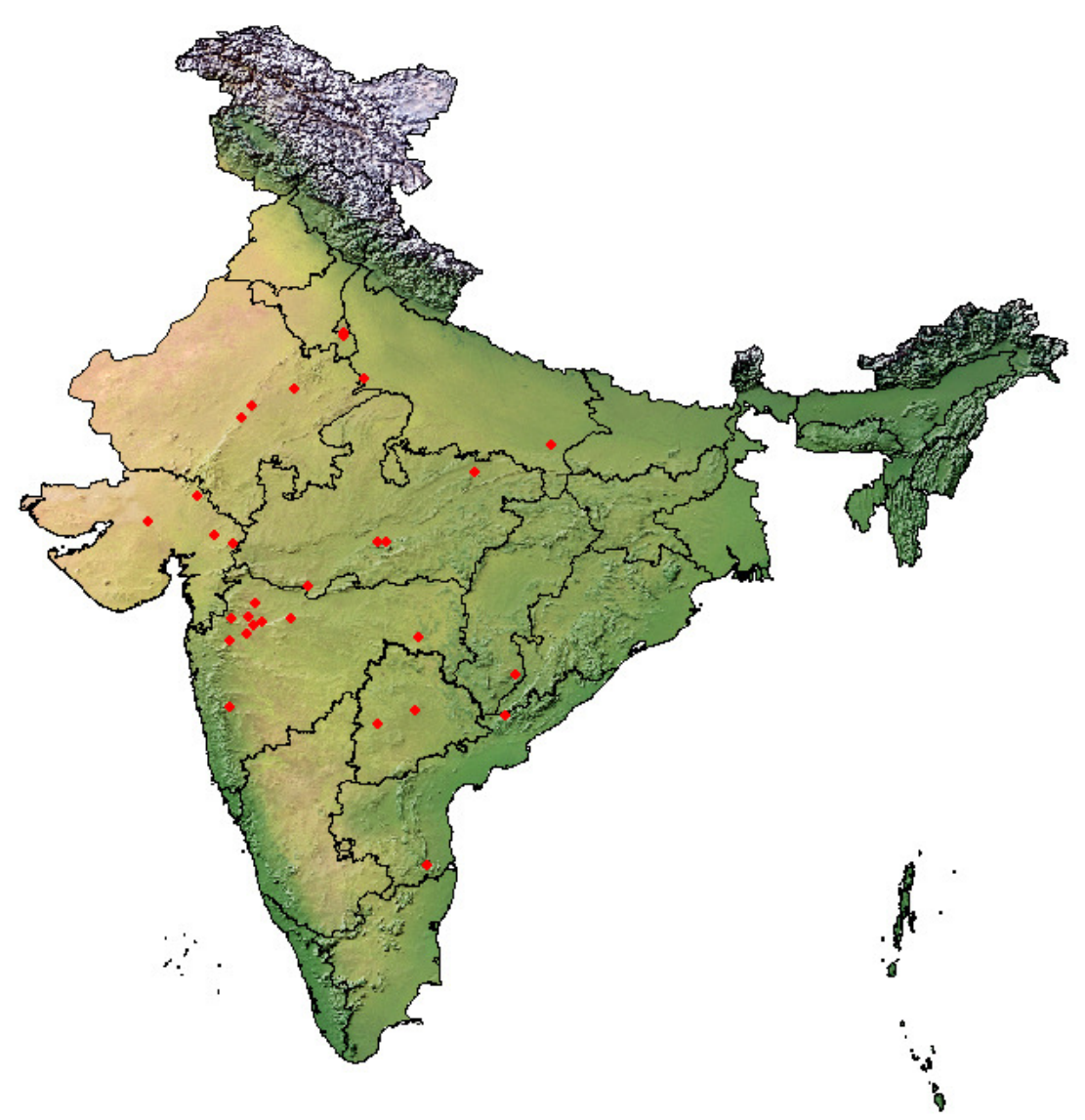

Figure 2. Distribution of Chersonesometrus fulvipes (C.L. Koch, 1837) in India

\section{Chersonesometrus madraspatensis (Pocock, 1900)}

Palamnaeus fulvipes madraspatensis Pocock, 1900: 88, 89 (part), fig. 25B

Material examined: 1 male (Juv.) NHM.OU.ARACH.3.2016 collected from Vikarabad (17.340N \& 77. 874E), Vikarabad District, Telangana State; collected by B. Ramakrishna.

Identification (Figure 1b): Juvenile male (Total length $53.15 \mathrm{~mm}$; Table 1) uniformly reddish brown, with yellowish legs. The telson is lighter than the rest of the body. The femur and patella of the pedipalp is long. Chela is lobiform with a length-to-width ratio of 2.2. Large, rounded granules with no carinae cover the manus. Patella of pedipalp with no discernible internal tubercle. Carapace is flat, granulate at the edges and tuberculate in the front. Moveable finger shorter than carapace length. The counts of pro- and retroventral spiniform macrosetae on the leg telotarsi are 4/5, 4/6, 4/6 \& 4/6. Pectinal teeth number 15/16 on either side. Telson is hirsute, with a vesicle as long as, if not longer than, that of aculeus.

Distribution: This species was detected only once during the present study at Vikarabad, Vikarabad District, Telangana State (Figure 3). However, it is historically reported from Bhoiguda, Secunderabad, Hyderabad District (Prendini and Loria, 2020).

\section{Genus Gigantometrus Couzijn, 1978}

Type species by original designation: Heterometrus swammerdami Simon, 1872 [= Gigantometrus swammerdami (Simon, 1872)]

Endemic to India and Sri Lanka. It includes two species - Gigantometrus swammerdami (Simon, 1872) and Gigantometrus titanicus (Couzijn, 1981).

One species, G. swammerdami (Simon, 1872), is known from Telangana State. 


\section{Gigantometrus swammerdami (Simon, 1872)}

Heterometrus swammerdamiSimon, 1872b: 54, 56-59, 97, 100, pl. VI, fig. 3

Material examined: 1 Male and 1 Female NHM.OU.ARACH.1.2015 collected from Yeddumailaram (17.500N \& 78.135E), Sangareddy District, Telangana State; collected by B. Ramakrishna. 1 Male NHM.OU.ARACH.7.2018 collected from Mandalapalli (17.252N \& 81.010E), Bhadradri Kothagudem District, Telangana State; collected by B. Ramakrishna.

Identification (Figure 1c): Adult male (Total length $124.98 \mathrm{~mm}$; Table 1) uniformly reddish black, with paler reddish black legs. The telson is lighter than the rest of the body and has some yellowish tinge. The femur and patella of the pedipalp is long. Chela strong and lobiform with a length-to-width ratio of 1.6. Broad rounded granules with no carinae cover the manus. Patella of pedipalp with no internal tubercle. The carapace has a smooth disc, granulate posterior part and margins, and the anterior part is granulate and tuberculate. Moveable finger longer than carapace length. The counts of pro- and retroventral spiniform macrosetae on the leg telotarsi are: $4 / 5,4 / 5,4 / 6 \& 4 / 6$. Pectinal teeth number $18 / 18$ on either side. Telson is bulbous and hirsute, with a vesicle longer than the aculeus.

Distribution: This species was detected from many places in Telangana State during the present study (Figure 4). However, only two specimens were collected from Yeddumailaram, Sangareddy District and one specimen was collected from Mandalapalli, Bhadradri Kothagudem District, Telangana State. This species is the most common Asian forest scorpion in Telangana State.

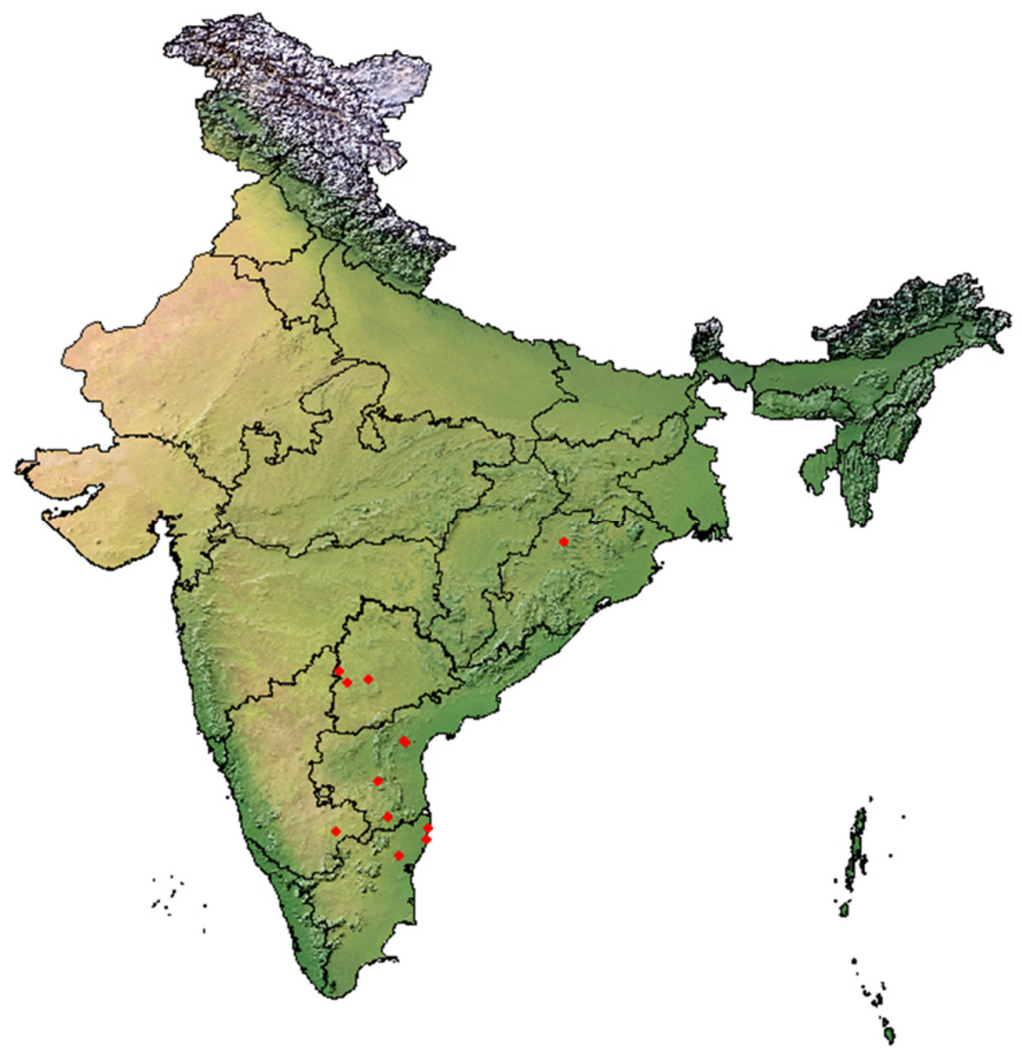

Figure 3. Distribution of Chersonesometrus madraspatensis (Pocock, 1900) in India 


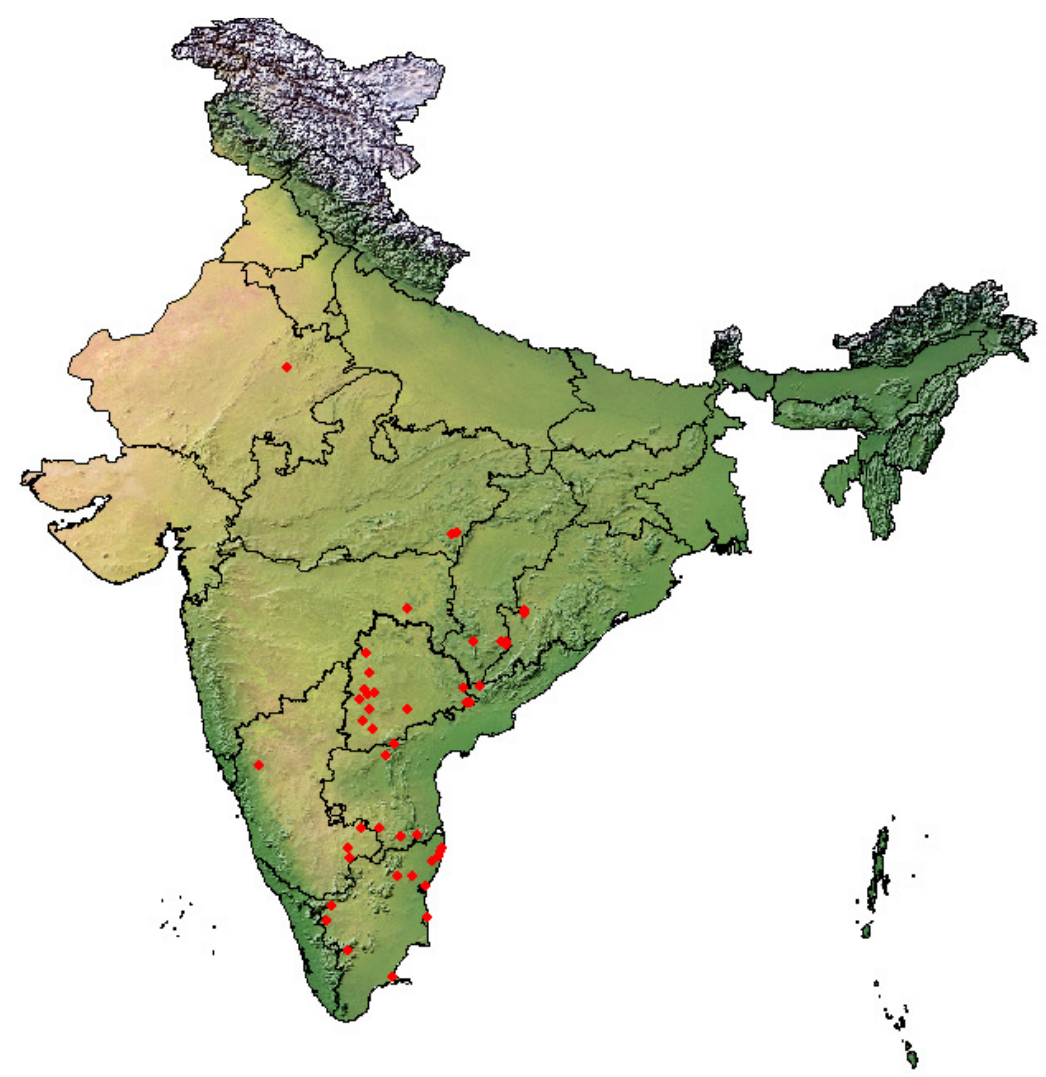

Figure 4. Distribution of Gigantometrus swammerdami (Simon, 1872) in India

\section{Genus Deccanometrus Prendini and Loria, 2020}

Type species by original designation: Heterometrus (Chersonesometrus) scaber obscurus Couzijn, 1981: 87, 146-149, 170, figs. 46, 58 [= Deccanometrus obscurus (Couzijn, 1981)

Occurs throughout India, China (in Tibet region), Nepal, and Pakistan. It includes seven species Deccanometrus bengalensis (C.L. Koch, 1841); Deccanometrus latimanus (Pocock, 1894); Deccanometrus liurus (Pocock, 1897); Deccanometrus obscurus (Couzijn, 1981); Deccanometrus phipsoni (Pocock, 1893); Deccanometrus ubicki (Kovařík, 2004); and Deccanometrus xanthopus (Pocock, 1897).

One species, D. xanthopus (Pocock, 1897), is known from Telangana State.

Deccanometrus xanthopus (Pocock, 1897)

Palamnaeus xanthopus Pocock, 1897: 116

Material examined: 1 Male ZSI/FBRC/A-32 collected from Regonda (18.233N \& 79.816E), Warangal District, Telangana State; collected by N. Goud.

Identification: Adult male (Total length $66.53 \mathrm{~mm}$; Table 1) uniformly reddish brown on carapace and metasoma and black on mesosoma, with yellowish brown legs. The telson is creamish brown. The femur and patella of the pedipalp are not long. Chela strong and lobiform with a length-to-width ratio of 1.9. Smooth suppressed granules cover the manus. Carinae are prominent on dorsal, external, internal margin, and movable and immovable fingers. The carapace is smooth on anterior region between lateral eyes, while coarsely granular on lateral and posterior region; posterior margin smooth, while lateral margin crenulated; anterior margin with a strongly pronounced concavity; anterior and posterior median furrow moderately developed; ocular tubercle fairly distinct in the centre of the carapace. Moveable finger shorter than carapace length. The counts of proand retroventral spiniform macrosetae on the leg telotarsi are: $3 / 4,3 / 4,4 / 5 \& 4 / 5$. Pectinal teeth number $11 / 11$ on either side. Telson is hirsute, with a long aculeus. 
Remarks: Heterometrus telanganaensis Javed et al. (2010) is in synonymy of this species (vide Prendini and Loria, 2020). 5).

Distribution: In Telangana State, this species is known only from Regonda in Warangal District (Figure

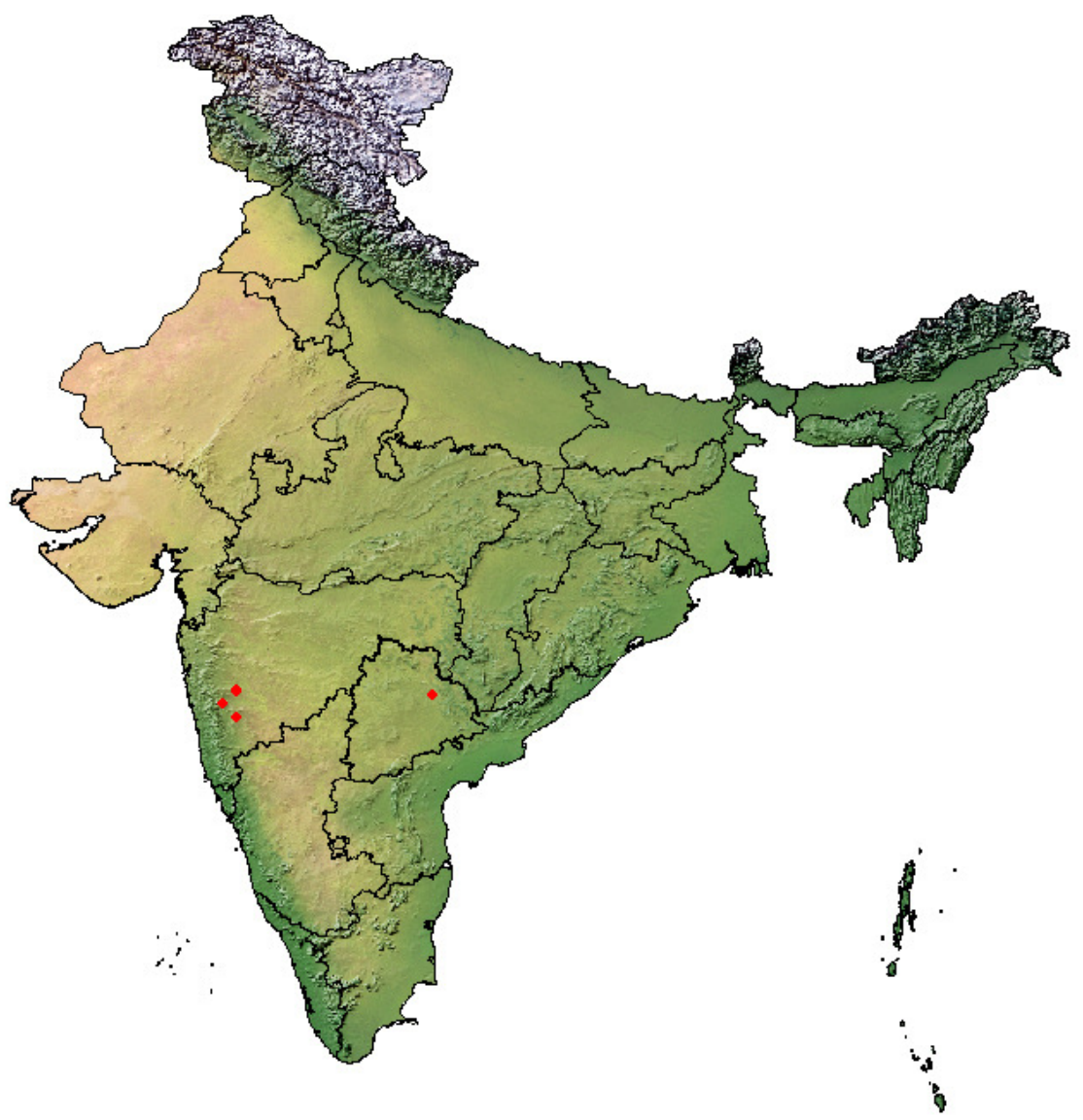

Figure 5. Distribution of Deccanometrus xanthopus (Pocock, 1897) in India

\section{Discussion}

The information on diversity and distribution of Asian forest scorpions in Telangana State is incomplete. For that matter of fact very few works have documented the true species diversity of these largebodied scorpions (Mohapatra, 2021). Furthermore, owing to the recent taxonomic revision of the forms belonging to the subfamily Heterometrinae by Prendini and Loria (2020), there was a necessity to present the information on the Asian forest scorpions known from Telangana State. During the present study we have detected four species of Asian forest scorpions in Telangana State and provide identification characters that could be helpful for future researches.

All the taxa of Asiatic forest scorpions found in Telangana State can be identified in having the following characters (summarized following Prendini and Loria, 2020): Rostrolateral margin of the carapace entire; median ocelli relatively small, with distance between the ocelli being equal to or greater than an ocellus width; pedipalp patella proventral carina without prominent spiniform granule; absence of the depression on the dorsal surface of the pedipalp chela manus proximal to fixed finger in adult males; legs I and II tibiae, pro- and 
retrolateral surfaces with row of two or three spiniform macrosetae; legs I-IV telotarsi, dactyl usually reduced and rounded.

The forms belonging to the genus Chersonesometrus Couzijn, 1978 are characterized by the distinct carinae on the pedipalp chela manus dorsal secondary, digital and retromedian; posteromedial median ocular tubercle on the carapace; distance from carapace anterior margin to carapace length ranging between 0.51-0.62; and more pronounced retromedian carinae on the pedipalp chela manus than digital carina.

The form belonging to the genus Gigantometrus Couzijn, 1978 is characterized by the anterolateral margins of the carapace, dorsal aspect, converging gradually anteriorly; anteromedial to medial median ocular tubercle on the carapace; superciliary carinae with anterocular extensions; interocular surface frontal lobes and medial region granular with smooth areas; distance from carapace anterior margin to carapace length ranging between 0.40-0.50; and not so pronounced retromedian carinae on the pedipalp chela manus; pedipalp chela manus dorsomedian carina continuous to proximal margin; metasomal segments I and II, length markedly greater than width; segment $\mathrm{V}$ dorsosubmedian carinae partially developed; in females the width of the vesicle of the telson greater than the width of the metasomal segment $\mathrm{V}$.

The form belonging to the genus Deccanometrus Prendini and Loria (2020) is characterized by the absence of carinae on the pedipalp chela manus dorsal secondary, digital and retromedian; carapace, pedipalps, tergites, and metasoma dark reddish or brownish black, dark reddish brown, pale yellowish brown or yellowish; legs often pale or lightly infuscate; presence of interocular suture on the carapace; posterior sutures present and extending past median ocular tubercle; and globose vesicle of the telson.

Habitat defragmentation and change in quality of habitats due to anthropogenic and biotic pressures have led to decline in the both the species diversity and distribution of these scorpions in particular. Owing to their large size, they are easily detected and killed by humans. In certain parts of India and Pakistan they are also harvested for their purported medicinal value (Majumder and Dey, 2005; Tahir and Prendini, 2014).

\section{Conclusions}

Four species of Asian forest scorpions occur in Telangana State, India. The diversity of the Asian forest scorpions could be more than currently known. Future studies and surveys in different parts of Telangana State with focus on forested tracts will yield further species hitherto undetected or new to science.

\section{Authors' Contributions}

Conceptualization CS; Field surveys BR and CS; Data curation BR and CS; Formal analysis BR and CS; Funding acquisition, Project administration, Resources, Software \& Supervision CS; Writing - original draft BR and CS; Writing - review and editing CS. Both authors read and approved the final manuscript.

Ethical approval (for researches involving animals or humans)

The scorpions are not protected species in India; thus, collection permits were not procured. Collected voucher specimen were sacrificed in field using $80 \% \mathrm{EtOH}$. 


\section{Acknowledgements}

We thank the Head, Department of Zoology, University College of Science, Osmania University, Hyderabad for providing facilities and encouragement. We acknowledge the microscopy facility of the Department under the UGC-DSA (SAP-II) programme. This work was supported by the fellowships to BR University Grants Commission (UGC), New Delhi under UPE programme and RFSMS programme.

\section{Conflict of Interests}

The authors declare that there are no conflicts of interest related to this article.

\section{References}

Bastawade DB, Jadhav SS, Sharma RM (2012). Scorpionida (online edition). Zoological Survey of India 4(6):1-16.

Couzijn HWC (1978). The method of polythetic analysis applied to a source of taxonomic difficulty: the genus Heterometrus H. and E., 1828 (Scorpionidae). Symposium of the Zoological Society of London 42:327-333.

Couzijn HWC (1981). Revision of the genus Heterometrus. Zoologische Verhandelingen 184:1-196.

Ehrenberg CG (1828). Heterometrus. In: Hemprich FG, Ehrenberg CG (Eds). Zoologica II. Arachnoidea. Plate I: Buthus; plate II: Androctonus. In: Symbolae physicae seu icones et descriptiones animalium evertebratorum sepositis insectis quae ex itinere per Africam borealem et Asiam occidentalem. Friderici Guilelmi Hemprich et Christiani Godofredi Ehrenberg, medicinae et chirurgiae doctorum, studio novae aut illustratae redierunt. Percensuit et regis iussu et impensis edidit Dr. C. G. Ehrenberg. Decas prima. ex Officina Academica, Venditur a Mittlero, Berlin.

Henderson JR (1919). Two new scorpions from southern India. Records of the Indian Museum 16:378-381.

Javed SMM, Mirza ZA, Tampal F, Lourenço WR (2010). A new species of the genus Heterometrus Ehrenberg, 1828 (Scorpiones: Scorpionidae) from India with notes on its natural history. Boletín de la Sociedad Entomológica Aragonesa 47:143-148.

Koch CL (1837). Die Arachniden. C.H. Zeh'sche Buchhandlung, Nürnberg 4(1-5):1-108, pl. 119-138 (figs. 253-318).

Koch CL (1841). Die Arachniden. C.H. Zeh'sche Buchhandlung, Nürnberg 9(1):1-56, pl. 289-306 (figs. 695-726).

Kovařík F (2004). A review of the genus Heterometrus Ehrenberg, 1828, with descriptions of seven new species (Scorpiones, Scorpionidae). Euscorpius 15:1-60.

Kraepelin K (1899). Scorpiones und Pedipalpi. In: Dahl F (Ed). Das Tierreich 8 (Arachnoidea). Herausgegeben von der Deutschen Zoologischen Gesellschaft. R. Friedländer und Sohn Verlag, Berlin, pp 265.

Latreille PA (1802). Histoire naturelle, generale et particuliere, des crustaces et des insectes. 3. (Ouvrage faisant suite à l'histoire naturelle générale et particulière, composée par Leclerc de Buffon, et redigée par C.S. Sonnini.). F. Dufart, Paris.

Loria SF, Prendini L (2020). Out of India, thrice: diversification of Asian forest scorpions reveals three colonizations of Southeast Asia. Scientific Reports 10:22301. https://doi.org/10.1038/s41598-020-78183-8

Loria SF, Prendini L (2021). Burrowing into the forest: Phylogeny of the Asian forest scorpions (Scorpionidae: Heterometrinae) and the evolution of ecomorphotypes. Cladistics 37(2):109-161. https://doi.org/10.1111/cla.12434

Majumder SC, Dey A (2005). Studies on some enthnomedicinal arachnids and insects in relation to their usage as drugs among the tribals of Sundarbans, West Bengal, India. Records of Zoological Survey of India, Occasional Paper 236:1-38.

Mirza ZA, Joshi D, Desouza G, Sanap RV (2012). Description of a new species of scorpion of the genus Heterometrus Ehrenberg, 1828 (Scorpiones, Scorpionidae) from the Western Ghats, India. Indian Journal of Arachnology 1:18.

Mohapatra PP (2021). Arachnida: Scorpionida. In: Chandra K, Deepa J, Raghunathan C, Jadhav SS, Karuthapandi M (Eds). Current status of faunal diversity in Telangana. Director, Zoological Survey of India, Kolkata, pp 73-78. 
Pocock RI (1893). Report upon a small collection of scorpions sent to the British Museum by Mr. Edgar Thurston, of the Government Central Museum, Madras. Journal of the Bombay Branch of the Royal Asiatic Society 7:295-312.

Pocock RI (1894). A small contribution to our knowledge of the scorpions of India. Annals and Magazine of Natural History (Ser. 6) 13:72-84.

Pocock RI (1897). Descriptions of some new species of scorpions from India. Journal of the Bombay Natural History Society 11:102-117.

Pocock RI (1899). Diagnoses of some new Indian Arachnida. Journal of the Bombay Natural History Society 12:744-753.

Pocock RI (1900). Arachnida. In: Blanford WT (Ed). The fauna of British India, including Ceylon and Burma. Taylor and Francis, London, pp 279.

Prendini L (2000). Phylogeny and classification of the superfamily Scorpionoidea Latreille 1802 (Chelicerata, Scorpiones): an exemplar approach. Cladistics 16:1-78.

Prendini L, Crowe TM, Wheeler WC (2003). Systematics and biogeography of the family Scorpionidae Latreille, with a discussion of phylogenetic methods. Invertebrate Systematics 17:185-259.

Prendini L, Loria SF (2020). Systematic revision of the Asian forest scorpions (Heterometrinae Simon, 1879), revised suprageneric classification of Scorpionidae Latreille, 1802, and revalidation of Rugodentidae Bastawade et al., 2005. Bulletin of the American Museum of Natural History 442:1- 480.

Rossi A (2016). Atlas of scorpions. Volume 1. (Scorpionidae: Pandininae: Pandinoides). Rivista Aracnologica Italiana 8:1148.

Shivashankar T (1994). Advanced subsocial behavior in the scorpion Heterometrus fulvipes Koch (Arachnida). Journal of Bioscience 19:81-90.

Simon E (1872). Études sur les scorpions. Révision des Heterometrus du groupe de l'H. afer, L [Studies on scorpions. Review of Heterometrus from the H. afer L.]. Revue et Magasin de Zoologie Pure et Appliquée 23:51-59; 97 101.

Simon E (1879). 3e Ordre. Scorpiones. In: Les arachnids de France. Tome VII. Contenant les ordres des Chernetes, Scorpiones et Opiliones. Librairie Encyclopédique de Rôret, Paris, pp 79-115.

Sissom WD (1990). Systematics, biogeography and paleontology. In: Polis GA (Ed). The biology of Scorpions. Stanford University Press, Stanford, CA, pp 64-160.

Sureshan PM, Bastawade DB, Radhakrishnan C (2007). Scorpion fauna (Arachnida: Scorpionida) of Parambikulam Wild Life Sanctuary, Kerala, India. Records of the Zoological Survey of India 107:49-54.

Tahir HM, Prendini L (2014). Redescription of Heterometrus latimanus and confirmation of the genus Heterometrus (Scorpiones: Scorpionidae) in Pakistan. American Museum Novitates 3805:1-23.

Thorell T (1876). On the classification of scorpions. Annals and Magazine of Natural History (Ser. 4) 17:1-15.

Tikader BK, Bastawade, DB (1983). Fauna of India. Vol. 3. Scorpions (Scorpionida: Arachnida). Zoological Survey of India. Sangam Press, Pune.
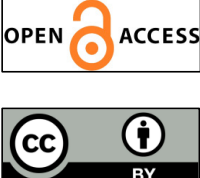

The journal offers free, immediate, and unrestricted access to peer-reviewed research and scholarly work. Users are allowed to read, download, copy, distribute, print, search, or link to the full texts of the articles, or use them for any other lawful purpose, without asking prior permission from the publisher or the author.

License - Articles published in Notulae Scientia Biologicae are Open-Access, distributed under the terms and conditions of the Creative Commons Attribution (CC BY 4.0) License.

(c) Articles by the authors; SHST, Cluj-Napoca, Romania. The journal allows the author(s) to hold the copyright/to retain publishing rights without restriction. 